\title{
QUALITY OF HEALTH CARE AND VIRAL SUPPRESSION AMONG HUMAN IMMUNODEFICIENCY VIRUS PATIENTS
}

\author{
Yonatan luna-Mireles, ${ }^{1}$ Svetlana V. Doubova, ${ }^{2 *}$ and Ricardo Pérez-Cuevas ${ }^{3}$ \\ ${ }^{1}$ Department of Health Sciences, Universidad Tecnológica de México, UNITEC México, Mexico State, Mexico; \\ ${ }^{2}$ Epidemiology and Health Services Research Unit, CMN Siglo XXI Mexican Social Security Institute, Mexico City, Mexico; \\ ${ }^{3}$ Inter-American Development Bank, Kingston, Jamaica.
}

\begin{abstract}
Background: In Mexico, the quality of health care for human immunodeficiency virus (HIV) patients is unknown. The study objectives were to develop quality of care $(\mathrm{Q} o \mathrm{C})$ indicators for outpatient care of HIV patients, evaluate the quality of the processes of care (QPC) and outcomes, and analyze the association between the QPC and viral suppression among HIV patients. Methods: The study used a mixed-methods approach: (1) Development of QoC indicators through RAND/UCLA method; (2) cross-sectional study of QoC evaluation; and (3) multiple Poisson regressions to measure the association between the QPC and viral suppression. The study included 439 HIV patients, $\geq 19$ years of age, with at least one outpatient consultation during 2017 at a public hospital in the State of Mexico. Results: We developed 21 QoC indicators to evaluate HIV care. Based on these indicators, the QoC gaps that emerged were related to clinical history (24\% of patient records included sexual history information), routine adherence assessment (no records demonstrated regular recording of antiretroviral treatment adherence), and screening and referral ( $50 \%$ were screened for depression, and $42 \%$ for tuberculosis; $1.2 \%$ of patients with abnormal body mass index were referred to a dietitian). On average, HIV patients received $63 \%$ of recommended QPC; $77.7 \%$ achieved viral suppression. Receiving over $75 \%$ of recommended QPC was associated with a higher probability of viral suppression (adjusted prevalence ratio $1.13,95 \%$ confidence interval 1.03-1.24). Conclusions: Evaluation of the QoC for HIV patients is essential to identify and address gaps in health-care quality to increase the probability of viral suppression. (REV INVEST CLIN. 2019;71:330-8)
\end{abstract}

Key words: Quality of care. Human immunodeficiency virus patients. Viral suppression.

\section{INTRODUCTION}

The human immunodeficiency virus (HIV) remains a significant global public health burden. Worldwide, in 2017, 1.8 million people became newly infected, 35

Corresponding author:

*Svetlana V. Doubova

Epidemiology and Health Services Research Unit

CMN Siglo XXI

Instituto Mexicano del Seguro Social

Av. Cuahutémoc, 330

Col. Doctores, Del. Cuahutémoc

C.P. 06720, Mexico City, Mexico

E-mail: svetlana.doubova@gmail.com million people continued living with HIV, and 940,000 people died from HIV-related causes, such as severe infections ${ }^{1}$. Besides, HIV patients are vulnerable to psychiatric conditions (e.g., depression) ${ }^{2}$ and may have nutritional disorders ${ }^{3,4}$. These comorbidities,
Received for publication: 08-01-2019

Approved for publication: 23-04-2019

DOI: 10.24875/RIC.19002952 
along with social stigma, negatively impact the quality of life and cause disability and premature deaths, mostly among working-age HIV patients ${ }^{5}$.

The lancet global commission on high-quality health systems (HQSS) highlighted that Universal Health Coverage would not lead to better health outcomes if the population does not receive high-quality health services $^{6}$. The complex outlook for HIV patients requires integrated, multidisciplinary, and evidencebased health care to reduce HIV transmission, achieve viral suppression, slow down or reverse disease progression, and improve quality of life. Multilateral organizations (e.g., The Joint United Nations Program on HIV/AIDS, and the Global Fund to fight AIDS, Tuberculosis, and Malaria) have proposed indicators to evaluate national HIV programs at the health systems-level. However, these indicators do not focus on processes for care continuum and do not reflect the multidisciplinary care that HIV patients require ${ }^{7}$. The HQSS commission and other studies identified that there is a lack of information regarding the quality of health-care processes and their impact on health outcomes, such as viral suppression, in most low- and middle-income countries, except for African countries $^{6-9}$. Existing evidence supports the following factors associated with viral suppression among HIVpositive individuals on antiretroviral treatment $(A R T)^{10-13}$ : older age; male sex; no history of injected drug use; low baseline viral load; and the type, adherence to, and longer duration of ART.

Mexico ranks fourth in Latin America regarding the number of people living with HIV and has increased its age-standardized rates of new infections between 2005 and $2015^{14}$. By the end of 2017, HIV had been diagnosed in 195,194 patients; most were men (82\%), particularly those who had sex with men, male sex workers, and drug users. Mexico City and the State of Mexico had the highest numbers of people with HIV in the country $(14.4 \%$ and $10.3 \%$, respectively) $)^{15}$. In Mexico, $65 \%$ of HIV-positive individuals are aware of their HIV status; $94 \%$ of those diagnosed have access to ART, and $84 \%$ are on viral suppres$\operatorname{sion}^{16}$. Public health-care institutions provide care to $99.2 \%$ of HIV patients ${ }^{17}$. Two out of three receive care at the Outpatient Centers for Prevention and Care of AIDS and Sexually Transmitted Infections (Spanish acronym CAPASITS), and Comprehensive Hospital Care Services (SAIH) under the Ministry of
Health. The remainders of patients are affiliated to social security institutes. Both CAPASITS and SAIH provide outpatient health-care through multidisciplinary groups that include physicians, psychologists, nurses, sex educators, and social workers.

In Mexico, little is known about the quality of the processes of care (QPC) that HIV patients receive. The indicators of the National Center for the Prevention and Control of HIV and AIDS (CENSIDA), CAPACITS and SAIH, focus primarily on epidemiological surveillance and health-care outcomes, such as retention in ART, viral suppression, and deaths, but do not address QPC. There are no studies that evaluate the association between QPC and viral suppression. Therefore, the study objectives were to develop valid quality of care (QoC) indicators to measure multidisciplinary outpatient hospital care services for HIVpatients, to evaluate the QPC and clinical outcomes, and to analyze the association between the QPC and viral suppression among HIV patients on ART.

\section{METHODS}

We conducted a three-stage research study with a mixed-methods approach. For the first stage, we developed the process and outcome indicators to evaluate the QoC of HIV patients using the modified RAND/ UCLA appropriateness method ${ }^{18}$, based on indicators selected through the review of scientific evidence and expert panel validation. A preliminary list of QoC indicators for expert vetting was identified through literature review that focused on those comprehensive, evidence-based care processes shown to increase the likelihood of achieving the best clinical outcomes of HIV patients. The review included eight clinical guidelines ${ }^{19-26}$ and seven sets of indicators previously proposed for HIV health-care evaluation $7,9,27-31$. The list of QoC indicators was divided into two groups: processes and clinical outcomes. A panel of eight HIV and health services experts (two health system researchers, two physicians specialized in infectious diseases, one psychologist, one nurse, one dietitian, and one social worker) validated the indicators. All members of the expert group had $\geq 10$ years of experience providing HIV care and/or health services research. The experts rated the validity and feasibility of proposed indicators using the Shekelle criteria ${ }^{32}$. These criteria allowed each expert to assess the indicators on a 1-9 scale. Only those 
indicators with a median score $\geq 7$ were considered valid and feasible to measure $\mathrm{QoC}^{33}$. The validation included three consensus group rounds (voting, feedback, and re-voting).

For the second stage, we conducted a cross-sectional study to evaluate the QoC at one SAlH of the Ministry of Health located in the State of Mexico. A multidisciplinary group of two physicians, a psychologist, a nurse, a sex educator, and a social worker provided HIV medical care in this facility. During 2017, this hospital offered health care to 440 HIV patients, providing 4538 medical consultations, 1384 psychological consultations, 1748 sexual counseling sessions, and 13 group sessions focused on ART adherence. One of the researchers (YLM) reviewed the clinical records of all HIV-positive patients $\geq 19$ years of age who had at least one medical consultation at SAlH during 2017. The QoC was evaluated through processes and outcome indicators, validated in the first stage of the study (Supplementary Table 1 ).

To describe the study population, we collected information on the following covariates: (1) patients' general characteristics: sex, age, schooling, and occupation; (2) history of sexual activity and use of illegal injected drugs: type of sexual orientation, age at first intercourse, number of sexual partners throughout life, serological status of the last sexual partner, condom use in the last month, condom use in the last intercourse, and use of illegal injected drugs; and (3) medical history: HIV patients with first consultation at SAIH in 2017, year of the first HIV-positive serology, pre-ART viral load, duration of antiretroviral therapy, coinfections, nutritional status at the first and last medical consultations measured through the body mass index (BMI) (malnutrition: $<18.5 \mathrm{~kg} / \mathrm{m}^{2}$, normal weight: $18.6-24.9 \mathrm{~kg} / \mathrm{m}^{2}$, overweight/obesity: > $25 \mathrm{~kg} / \mathrm{m}^{2}$ ), number of consultations in 2017 , patients with suspected depression or presence of two or more depression-related symptoms, and patient status at the end of 2017.

The third stage of the study investigated the association between QPC and viral suppression ( $<50$ copies/ $\mathrm{mL}$ ). We created a process's summary binary indicator. First, we calculated the percentage of recommended QPC using McGlynn et al. approach ${ }^{33}$. The numerator was the sum of all the recommended QPC indicators that the HIV patient received, and the denominator was the total number of indicators for which he/she was eligible. Then, since we identified that the percentage of recommended QPC did not show a normal distribution, we dichotomized QPC as follows: HIVpatients receiving $75 \%$ or higher of recommended QPC and those receiving $<75 \%$. The cutoff value was based on the $80^{\text {th }}$ percentile of QPC.

The National Institute of Public Health Research and Ethics Committees approved the study protocol (Register PT Cl: 427, folio identifier O65).

\section{Statistical analysis}

The units of observation to measure QoC and the units of analysis were HIV-patients. We used descriptive statistics to analyze the characteristics of HIVpatients and the health care they received. To fulfill the third objective, we performed a multiple Poisson regression model with robust variance as recommended for cross-sectional studies with high-prevalence binary outcomes ${ }^{34}$. The multiple Poisson regression model included the dependent variable (viral suppression), the independent variable (QPC $\geq 75 \%$ ), and all conceptually relevant covariates identified through literature review and reported in the introduction section. Stata 14.0 (Stata Corp, College Station, Texas, United States) served for the analysis; $\mathrm{p}$ $<0.05$ was considered statistically significant.

\section{RESULTS}

\section{Stage1: Development of processes and outcomes indicators of QoC}

After literature review, 24 QoC indicators were proposed and sent to the experts for validation. The panel discarded six indicators, suggested three new indicators, modified four indicators, and finally agreed on 21 indicators. The primary reason for dropping indicators was that some activities (oral cavity examination, patient information on ART goals, social programs, support groups, and sexual-reproductive counseling) did not require registration in the patients' health records. The main reason for modifications was the local unavailability of some tests (e.g., Mantoux test for tuberculosis screening, among others). A final list of approved indicators included 18 QPC indicators and three outcome indicators. The QPC were 
organized in two domains: (i) clinical history, laboratory tests and treatment of HIV and coinfections (13 indicators); and (ii) care integration that included health care for nutritional and psychological issues and follow-up by a social worker (five indicators) (Supplementary Table 1).

\section{Stage 2: QoC evaluation}

Supplementary table 2 describes the general characteristics and history of sexual relationships of 439 HIV-patients, who attended SAIH in 2017. Most were men $(78.6 \%)$, between 30 and 49 years of age (61\%), with completed secondary school or high school education ( $28.9 \%$ and $27.3 \%$, respectively); unskilled workers ( $44.4 \%$ ), and unemployed (22.6\%). Overall, $43.5 \%$ reported having a heterosexual orientation. On average, HIV patients had their first intercourse at 17.2 years of age. Furthermore, $28.5 \%$ reported having more than 10 sexual partners throughout life. Only $35.3 \%$ knew the serological status of their last sexual partner, among whom $28.5 \%$ were HIV-positive; however, only $3 \%$ reported always using a condom in the last month, including the last intercourse; $0.9 \%$ had a history of illegal injected drug use.

Table 1 presents the medical history of HIV-patients; $11.4 \%$ attended their first SAIH consultation in 2017. Most had their first HIV-positive serology between 2001-2010 (43.5\%) and 2011-2016 (41.7\%); 50.4\% had an initial viral load $\geq 100,000$ copies $/ \mathrm{mL}$. The mean duration of the ART was 85.9 months. In addition to HIV, $17.1 \%$ had coinfections, including syphilis (8\%), tuberculosis $(7.3 \%)$, hepatitis C (2.1\%), and hepatitis B (1.4\%). Normal nutritional status was found in $53.6 \%$, $5.9 \%$ were malnourished, and the rest had overweight or obesity at the first consultation of 2017; depression was suspected in $21 \%$. The patients attended 8.9 consultations on average. The status reported at the end of 2017 was: continues follow-up in the hospital $(83.4 \%)$, death $(0.5 \%)$, dropped out $(0.7 \%)$, changed address/hospital $(0.7 \%)$, changed health insurance (14.1\%), and without information (0.7\%).

Supplementary table 3 shows results of the QoC evaluation. Only $24 \%$ of the new HIV patients had the minimum-required information on sexual history at the initial medical consultation, while all had at least one absolute and percentage counts of CD4 lymphocytes, and viral loads. Regarding the subsequent patients, $78.9 \%$ had absolute and percentage counts of CD4 lymphocytes and viral loads as recommended by the clinical guidelines. Furthermore, a viral resistance test was performed in $78.6 \%$ of patients who had two consecutive viral loads $>1000$ copies/ $\mathrm{mL}$ during follow-up. In addition, $91.8 \%$ had liver function tests, creatinine and lipid profile completed at least once during 2017. Serological tests for hepatitis $B$ and $C$ were performed in $56.6 \%$ patients who had $\geq$ 1 risk factor at the initial visit; $80.6 \%$ had venereal disease research laboratory test for syphilis detection. A chest radiograph was done in $41.7 \%$ of patients with $\geq 1$ risk factor for tuberculosis. Regarding HIV treatment, $79.5 \%$ of new HIV patients had ART initiation once the diagnosis was confirmed; $50 \%$ of patients with virological failure had a change of the ART scheme. Adherence was not registered in each medical visit. Moreover, $89 \%$ of patients with more than 6 months of ART and with $<200 \mathrm{CD} 4$ cells $/ \mathrm{mm}^{3}$ and $<$ $14 \%$ CD4 initiated prophylaxis of opportunistic infections with trimethoprim-sulfamethoxazole.

Only $1.2 \%$ of patients with malnutrition or obesity were referred to the nutrition service. About $50 \%$ of new HIV-patients were screened for depression; however, $96.7 \%$ of those with the diagnosis of probable depression were referred to the psychology/psychiatry service. Of the sexually active patients, $48.1 \%$ received a supply/donation of condoms at each appointment. A social worker followed up on $28.7 \%$ of patients who missed two consecutive monthly appointments. The mean number of QPC indicators for which each patient was eligible was 8.7 , ranging between 6 and 14 indicators. The mean percentage of recommended QPC was 63.0\%, ranging from 0 to 90 . Only $30.5 \%$ of patients received $75 \%$ or more of recommended QPC. Regarding health outcomes, 81\% of patients were alive and on treatment at 12 and 24 months after ART initiation; $77.7 \%$ with $\geq 6$ months on ART presented viral suppression for at least 6 months.

\section{Stage 3: Association between QPC and viral suppression}

Table 2 describes the results of the Poisson regression analysis. The analysis was performed in 409 patients out of 417 with $\geq 6$ months of ART. Eight patients had one or more missing data on the study variables; therefore, they were excluded from the analysis. Both 
Table 1 . Medical history and health care of HIV-patients $(n=439)$

\begin{tabular}{|c|c|}
\hline New HIV patients with the first consultation at SAI in 2017 & $50(11.4)$ \\
\hline$\leq 2000$ & $28(6.4)$ \\
\hline $2001-2010$ & $191(43.5)$ \\
\hline 2017 & $37(8.4)$ \\
\hline \multicolumn{2}{|l|}{ Pre-ART viral load (copies/mL) } \\
\hline$<10,000$ & $73(16.6)$ \\
\hline $10,000-99,999$ & $136(31.0)$ \\
\hline \multicolumn{2}{|l|}{ Duration of antiretroviral therapy, months } \\
\hline Mean (SD) & $85.9(66.2)$ \\
\hline Median (minimum-maximum) & $74(0-289)$ \\
\hline Coinfections $^{\dagger}$ & $75(17.1)$ \\
\hline Syphilis & $35(8.0)$ \\
\hline Tuberculosis & $32(7.3)$ \\
\hline Hepatitis C & $9(2.1)$ \\
\hline Hepatitis B & $6(1.4)$ \\
\hline \multicolumn{2}{|l|}{ Nutritional status } \\
\hline Normal & $214(48.8)$ \\
\hline Overweight/obesity & $196(44.6)$ \\
\hline Not registered & $1(0.2)$ \\
\hline \multicolumn{2}{|l|}{ Psychological status } \\
\hline $\begin{array}{l}\text { Registered diagnosis of depression, or probable depression, or } \\
\text { presence of } \geq 2 \text { depression-related symptoms during } 2017\end{array}$ & $92(21.0)$ \\
\hline \multicolumn{2}{|l|}{ Number of consultations in 2017} \\
\hline Mean (SD) & $8.9(3.2)$ \\
\hline Median (minimum-maximum) & $10(1-12)$ \\
\hline \multicolumn{2}{|l|}{ Status at the end of 2017} \\
\hline Continue follow-up in the hospital & $366(83.4)$ \\
\hline Death & $2(0.5)$ \\
\hline Drop-out (loss to follow-up) & $3(0.7)$ \\
\hline Change of address and hospital & $3(0.7)$ \\
\hline Change in health insurance & $62(14.1)$ \\
\hline Not registered & $3(0.7)$ \\
\hline
\end{tabular}

${ }^{\dagger} 7$ patients have more than one coinfection. ART: antiretroviral treatment; HIV: human immunodeficiency virus; SD: standard deviation. 
Table 2. Association between the quality of health care and viral suppression of HIV patients $(n=409)$

\begin{tabular}{|c|c|c|}
\hline Variable & Crude PR $[95 \% \mathrm{Cl}], \mathrm{p}$ & Adjusted PR $[95 \% \mathrm{Cl}], \mathrm{p}$ \\
\hline Recommended QPC $\geq 75 \%$ & $1.16[1.05-1.28], 0.003$ & $1.13[1.03-1.24], 0.012$ \\
\hline \multicolumn{3}{|l|}{ Covariates } \\
\hline $\begin{array}{l}\text { Gender } \\
\text { Male } \\
\text { Female }\end{array}$ & $\begin{array}{c}0.94 \text { [0.84-1.06], } 0.354 \\
\text { Ref. }\end{array}$ & $\begin{array}{c}0.89 \text { [0.77-1.02], } 0.095 \\
\text { Ref. }\end{array}$ \\
\hline $\begin{array}{l}\text { Age } \\
\leq 29 \text { years } \\
30-49 \text { years } \\
\geq 50 \text { years }\end{array}$ & $\begin{array}{c}1.13 \text { [0.94-1.36], } 0.188 \\
1.16 \text { [0.99-1.35], } 0.064 \\
\text { Ref. }\end{array}$ & $\begin{array}{c}1.18[0.96-1.45], 0.116 \\
1.17 \text { [1.002-1.36], } 0.046 \\
\text { Ref. }\end{array}$ \\
\hline $\begin{array}{l}\text { Schooling } \\
\text { Completed elementary school or less } \\
\text { Completed secondary school } \\
\text { Completed high school, or technical career } \\
\text { Completed bachelor's degree or higher }\end{array}$ & $\begin{array}{c}1.15[0.94-1.41], 0.171 \\
1.15[0.94-1.41], 0.163 \\
1.14[0.93-1.40], 0.204 \\
\text { Ref. }\end{array}$ & $\begin{array}{c}1.21[0.97-1.51], 0.083 \\
1.18[0.95-1.47], 0.123 \\
1.18 \text { [0.95-1.46], } 0.135 \\
\text { Ref. }\end{array}$ \\
\hline $\begin{array}{l}\text { Occupation } \\
\text { Housekeeper } \\
\text { Unskilled worker } \\
\text { Semiskilled work } \\
\text { Qualified work (professional) } \\
\text { Unemployed } \\
\text { Student }\end{array}$ & $\begin{array}{c}\text { Ref. } \\
0.96[0.82-1.13], 0.653 \\
0.96[0.75-1.23] .0 .762 \\
0.82[0.60-1.10], 0.186 \\
1.03[0.87-1.23], 0.703 \\
1.10[0.90-1.34], 0.352\end{array}$ & $\begin{array}{c}\text { Ref. } \\
1.07[0.89-1.28], 0.450 \\
1.05[0.81-1.38], 0.694 \\
1.01[0.72-1.40], 0.967 \\
1.14[0.93-1.39], 0.193 \\
1.25[0.95-1.65], 0.102\end{array}$ \\
\hline $\begin{array}{l}\text { Sexual orientation } \\
\text { Homosexual } \\
\text { Bisexual } \\
\text { Heterosexual }\end{array}$ & $\begin{array}{c}0.95[0.82-1.10], 0.511 \\
\text { Ref. } \\
1.007 \text { [0.88-1.16], } 0.919\end{array}$ & $\begin{array}{c}1.01[0.87-1.16], 0.941 \\
\text { Ref. } \\
1.04[0.90-1.20], 0.597\end{array}$ \\
\hline $\begin{array}{l}\text { Coinfections } \\
\text { Yes } \\
\text { No }\end{array}$ & $\begin{array}{c}0.92 \text { [0.79-1.07], } 0.284 \\
\text { Ref. }\end{array}$ & $\begin{array}{c}1.001 \text { [0.87-1.15], } 0.989 \\
\text { Ref. }\end{array}$ \\
\hline $\begin{array}{l}\text { Pre-ART viral load (copies/mL) } \\
\quad<10,000 \\
10,000-99,999 \\
100,000-500,000 \\
>500,000\end{array}$ & $\begin{array}{c}1.29[1.06-1.57], 0.012 \\
1.29[1.07-1.55], 0.007 \\
1.18[0.97-1.42], 0.096 \\
\text { Ref. }\end{array}$ & $\begin{array}{c}1.31[1.09-1.57], 0.003 \\
1.32[1.12-1.56], 0.001 \\
1.1 \mid 8[0.99-1.41], 0.068 \\
\text { Ref. }\end{array}$ \\
\hline Duration of antiretroviral therapy, months & $1.001[1.0008-1.0002],<0.0001$ & $1.001[1.0006-1.002], 0.001$ \\
\hline Number of consultations in 2017 & $1.05[1.03-1.08],<0.0001$ & 1.05 [1.03-1.07], < 0.0001 \\
\hline
\end{tabular}

ART: antiretroviral treatment; QPC: quality of the processes of care; PR: prevalence ratio; Cl: confidence interval; HIV: human immunodeficiency virus.

Prevalence ratios (PRs), crude and adjusted by the conceptually relevant covariates, revealed that having $\geq 75 \%$ of recommended QPC increases the probability of viral suppression (adjusted PR: 1.13; $95 \%$ confidence interval $[\mathrm{Cl}]$ : 1.03-1.24). Other covariates that increased the probability of viral suppression were: age $30-49$ years (adjusted PR: 1.17; $95 \%$ $\mathrm{Cl}: 1.002-1.36$ ), pre-ART viral load $<10,000$ copies/ $\mathrm{mL}$ (adjusted PR:1.31; $95 \% \mathrm{Cl}: 1.09-1.57$ ), and preART viral load 10,000-99,999 copies/mL (adjusted PR: 1.32 ; $95 \% \mathrm{Cl}: 1.12-1.56$ ), higher duration of ART (adjusted PR: $1.001 ; 95 \% \mathrm{Cl}: 1.0006-1.002$ ), and a higher number of medical consultations (adjusted PR: 1.05 ; 95\% Cl: 1.03-1.07).

\section{DISCUSSION}

The study validated 21 indicators useful for QoC evaluation of the multidisciplinary outpatient hospital care services for HIV patients. The utilization of these indicators in one public hospital allowed identifying gaps in the QoC, showing that on average, HIV patients received merely $63 \%$ of the recommended 
QPC, and only $77.7 \%$ achieved viral suppression. Furthermore, receiving over $75 \%$ of recommended QPC was associated with a higher probability of viral suppression. The QoC evaluation is essential for accountability and improvement actions at the health facility and health system levels ${ }^{10}$. QoC indicators at the health facilities require local relevance and feasibility to provide more detailed information on QPC and guide onsite quality improvement efforts. The pilot use of the validated QoC indicators allowed identifying quality gaps in health care for HIV patients. The most significant gaps were: (1) insufficient record of sexual history at the initial medical consultation; (2) absence of verification and registration of adherence to prescribed ART during the medical visit; (3) lack of follow-up and rescheduling of appointments for patients who missed two consecutive appointments; (4) deficiency of referral of patients with abnormal BMI to a nutrition specialist; (5) low frequency of screening for depression in new HIV patients; and (6) deficiency in the early detection of tuberculosis in patients with risk factors.

Insufficient records of the sexual history of HIV-patients (sexual orientation, partners, practices, and protection) represent a missed opportunity for counseling on the prevention of contracting other sexually transmitted diseases, further HIV transmission to sexual partners, partner notification, and ART treatment of HIV-positive sexual partners ${ }^{35}$. In our study, only $24 \%$ of new HIV patients had the minimum-required information on their sexual history.

To sustain viral suppression, $95 \%$ of adherence to ART is required ${ }^{36}$. Non-adherence is related to the development of ART resistance, progression to AIDS, and death ${ }^{37,38}$. However, adherence to ART varies among countries, from $55 \%$ in North America (Canada and US) to $77 \%$ in sub-Saharan Africa ${ }^{39}$, and up to $70 \%$ in Latin America and the Caribbean ${ }^{40}$. Regular assessment of patient adherence to ART is an important health-care process aimed at timely detection and counseling of patients with non-adherence. Our study identified that physicians did not record information on ART adherence; furthermore, only $28 \%$ of patients who missed two consecutive monthly appointments received follow-up and rescheduled the appointment.

HIV-patients can be malnourished, overweight, or obese. Malnourishment may be due to reduced appetite, diarrhea, and poor absorption of nutrients caused either by infection or as a side effect of medications ${ }^{41}$. Furthermore, those patients who are on ART and have reached viral suppression can be obese due to the adverse effects of some ARTs, an unhealthy diet, and physical inactivity increasing their risk for chronic non-communicable diseases ${ }^{42}$. We found that $6 \%$ of patients were malnourished and $44 \%$ were overweight, although only $1.2 \%$ were referred to the nutrition specialist. Nutritional assessment and counseling improve health-related outcomes in HIV patients ${ }^{43}$; thus, referral of patients with under or overweight to the nutrition specialist should be mandatory to achieve better health outcomes.

Compared to the general population, more HIV patients are depressed. Up to $30 \%$ of HIV-patients suffer from depression ${ }^{44-46}$, which is associated with risky behavior and lower adherence to ART ${ }^{47}$. Early detection and treatment of depression are essential components of the health care of HIV patients. In our study, only $50 \%$ of new HIV patients underwent screening for depression. However, $96.7 \%$ of patients in whom depression was suspected were referred to psychiatric services; this result shows the general awareness of health professionals about the need for specialized treatment of psychological problems.

Due to the impaired function of the immune system, HIV patients are 20 times more likely to fall ill with tuberculosis than non-HIV-patients ${ }^{48}$. As tuberculosis is a frequent ( $32 \%$ ) cause of death among HIV-patients ${ }^{48}$, multiple evidence-based clinical guidelines recommend timely detection and treatment of this condition in HIV patients. However, in our study, only $41.7 \%$ of patients without a previous diagnosis and with one or more risk factors for this disease had a chest radiograph.

The QPC gaps identified in this study highlight the importance of implementation of QoC improvement activities. The Lancet Global HQSS Commission emphasizes that improving quality requires action at both facility and health system levels. At the system level, improvement actions should focus on QoC foundations, such as governance, workforce, platforms, tools, and population that allow strengthening of QPC at facility levels ${ }^{6}$. Mainly, electronic health records with standardized formats that include questions on sexual history can be essential tools to promote sexual history registration through automatic alerts/reminders and compulsory registries ${ }^{49}$. Furthermore, the adoption of 
competency-based pre-clinical and continuous in-practice training of health professionals and the active implementation of clinical guidelines in daily practice are fundamental to providing high-quality health care ${ }^{6}$. These actions at the health system level should be reinforced at the local level through improvement activities focused on the specific gaps identified at the facility.

Our study found that only $77.7 \%$ of HIV patients with ART had achieved viral suppression. This figure is lower than $90 \%$ proposed as one of three global targets for HIV treatment to help end the AIDS epidemic. Improvement of QPC for HIV patients may increase the probability of viral suppression, given that our statistical analysis revealed that having $\geq$ $75 \%$ of recommended QPC was associated with a 1.13 higher likelihood of viral suppression after adjusting for other relevant covariates. To the best of our knowledge, this is the first study that identified this association, as previous studies focused primarily on patient sociodemographic (sex, age, and education) and clinical (baseline viral load, and type, adherence to and duration of ART) characteristics.

This study faced several limitations. First, our measurement of QoC relied on the review of health record data and therefore, could overestimate or underestimate the QoC, as it is possible that some processes of care may have been performed during the consultations without being registered or vice versa. However, the experience of other studies that analyzed health records in Mexico suggests that, in general, they accurately reflect the actions taken during consultations ${ }^{50}$. Furthermore, to avoid the potential bias during the development of QPC, we used the rigorous RAND/UCLA Appropriateness Method that combines scientific evidence and expert consensus; moreover, we secured the multidisciplinary character of the expert group and their extensive clinical and research experience. Second, the study was conducted in one public hospital, which means that the results may not be representative of all hospitals that provide care to HIV patients in Mexico. Nevertheless, the indicators developed in this study can be used to evaluate and to compare the QoC of HIV patients in other health settings in Mexico with characteristics similar to the studied hospital (e.g., HIV out-patient services at the public hospitals), or can be adopted and adapted in other countries through the expert evaluation of their applicability to the country and facility-specific context. Third, the study evaluates only technical QPC and health outcomes, without addressing the patient experience, an important sub-domain of the processes of care. Finally, this is a cross-sectional study; therefore, it does not allow for inferences about causal relationships between the QPC and viral suppression. We conclude that the development of valid QoC indicators to measure multidisciplinary outpatient care services for HIV patients in Mexico is an important step to identify and address gaps in quality to boost better health outcomes.

\section{ACKNOWLEDGMENTS}

The authors would like to thank the team of experts who participated in the validation of indicators: Karla A. Romero-Mora MD, and Francisco J. Quezada-Juárez $\mathrm{MPH}$, from the Infectious Diseases Research Center in Mexico City; Aldo Gutiérrez-Ortega MD and Paulina Fragoso BSN, from the CAPASITS Tlalnepantla; Víctor Rodríguez-Pérez (Psychologist), Andrea Peña BSW, and Evelin Mitzilitzin Molina Gallegos (DDS Orthodontics Specialty Degree), from the Condesa Specialized Clinic.

\section{SUPPLEMENTARY DATA}

Supplementary data are available at Clinical and Translational Investigation (Revista de Investigación Clínica) online (www.clinicalandtranslationalinvestigation.com). These data are provided by the corresponding author and published online for the benefit of the reader. The contents of supplementary data are the sole responsibility of the authors.

\section{REFERENCES}

1. World Health Organization. HIV/AIDS. Key facts: 19 July 2018. Available from: http://www.who.int/news-room/fact-sheets/ detail/hiv-aids.

2. Remien RH, Rabkin JG. Psychological aspects of living with HIV disease: a primary care perspective. West J Med. 2001;175:332-5.

3. Mangili A, Murman DH, Zampini AM, Wanke CA. Nutrition and HIV infection: review of weight loss and wasting in the era of highly active antiretroviral therapy from the nutrition for healthy living cohort. Clin Infect Dis. 2006;42:836-42.

4. Crabtree-Ramírez B, Del Río C, Grinsztejn B, Sierra-Madero J. HIV and noncommunicable diseases (NCDs) in Latin America: a call for an integrated and comprehensive response. J Acquir Immune Defic Syndr. 2014;67 Suppl 1:S96-8.

5. Cardona-Arias JA, Higuita-Gutiérrez LF. Impact of HIV/AIDS on quality of life: meta-analysis 2002-2012. Rev Esp Salud Publica. 2014:88:87-101. 
6. Kruk ME, Gage AD, Arsenault C, Jordan K, Leslie HH, RoderDeWan $S$, et al. High-quality health systems in the sustainable development goals era: time for a revolution. Lancet Glob Health. 2018;6:e1196-252.

7. Ahonkhai AA, Bassett IV, Ferris TG, Freedberg KA. Improving HIV outcomes in resource-limited countries: the importance of quality indicators. BMC Health Serv Res. 2012;12:427.

8. Engelhard EA, Smit C, Nieuwkerk PT, Reiss P, Kroon FP, Brinkman $K$, et al. Structure and quality of outpatient care for people living with an HIV infection. AIDS Care. 2016;28:1062-72.

9. Catumbela E, Certal V, Freitas A, Costa C, Sarmento A, da Costa Pereira A, et al. Definition of a core set of quality indicators for the assessment of HIV/AIDS clinical care: a systematic review. BMC Health Serv Res. 2013;13:236

10. Cescon AM, Cooper C, Chan K, Palmer AK, Klein MB, Machouf $\mathrm{N}$, et al. Factors associated with virological suppression among HIV-positive individuals on highly active antiretroviral therapy in a multi-site canadian cohort. HIV Med. 2011:12:352-60.

11. Joao EC, Gouvêa MI, Menezes JA, Sidi LC, Cruz ML, Berardo PT, et al. Factors associated with viral load suppression in HIV-infected pregnant women in Rio de Janeiro, Brazil. Int J STD AIDS. 2012;23:44-7

12. O'Connor J, Smith C, Lampe FC, Johnson MA, Chadwick DR, Nelson $M$, et al. Durability of viral suppression with first-line antiretroviral therapy in patients with HIV in the UK: an observational cohort study. Lancet HIV. 2017;4:e295-302.

13. Bulage L, Ssewanyana I, Nankabirwa V, Nsubuga F, Kihembo C, Pande $G$, et al. Factors associated with virological non-suppression among HIV-positive patients on antiretroviral therapy in Uganda, august 2014-july 2015. BMC Infect Dis. 2017;17:326.

14. GBD 2015 HIV Collaborators. Estimates of global, regional, and national incidence, prevalence, and mortality of HIV, 19802015: the global burden of disease study 2015. Lancet HIV. 2016;3:e361-87

15. Secretaría de Salud. Centro Nacional para la Prevención y el Control del VIH y el SIDA (Censida). Epidemiological Surveillance of HIV/AIDS Cases in Mexico National Registry of AIDS Cases. Mexico: secretaría de Salud; 2017

16. Gutierrez C, Lavadenz F, Macías C, Petravic J, Lavadenz L. Health Nutrition and Population (HNP) Discussion Paper. Optimizing Investments in the National HIV Response of Mexico. Washington DC: the International Bank for Reconstruction and Development/The World Bank; 2018.

17. Secretaría de Salud. Centro Nacional para la Prevención y el Control del VIH y el Sida (Censida). National Report on Progress in the Response to HIV and AIDS. Mexico: secretaría de Salud; 2016.

18. Campbell SM, Braspenning J, Hutchinson A, Marshall MN. Research methods used in developing and applying quality indicators in primary care. BMJ 2003:326:816-9.

19. Secretaría de Salud. Antiretroviral Treatment of the Adult Patient with HIV Infection. Clinical Practice Guideline. Mexico: Gobierno Federal; 2017.

20. Secretaría de Salud. Centro Nacional para la Prevención y el Control del VIH y el SIDA (Censida). Guideline for Antiretroviral Management of People with HIV. Novena Edición. México: censida/Secretaría de Salud: 2018.

21. U.S. Department of Health and Human Services. Health Resources and Services Administration, Guide for HIV/AIDS Clinical Care. Rockville MD. US. Department of Health and Human Services. 2014.

22. DHHS Guidelines for the Use of Antiretroviral Agents in Adults and Adolescents Living with HIV. Department of Health and Human Services; 2017.

23. Churchill D, Waters L, Ahmed N, Angus B, Boffito M, Bower M, et al. British HIV association guidelines for the treatment of HIV-1-positive adults with antiretroviral therapy 2015. HIV Med. 2016;17 Suppl 4:s2-104

24. European AIDS Clinical Society. Guidelines. Version 9. EACS; 2017. Available from: http://www.eacsociety.org/files/guidelines_9.0english.pdf.

25. WHO Guidelines Approved by the Guidelines Review Committee. Consolidated Guidelines on the use of Antiretroviral Drugs for Treating and Preventing HIV Infection: recommendations for a Public Health Approach. 2nd ed. Geneva: world Health Organization; 2016

26. Polo R, Gómez-Candela C, Miralles C, Locutura J, Álvarez J, Barreiro F, et al. Recomendaciones de SPNS/GEM/SENPE/AEDN/ SEDCA/GESIDA Sobre Nutrición en el Paciente con Infección por VIH. España: ministerio de Sanidad y Consumo; 2006.

27. UNAIDS. Global AIDS Monitoring 2017. Indicators for Monitoring the 2016 United Nations Political Declaration on Ending AIDS. 2017 GUIDANCE Geneva: UNAIDS; 2017.
28. PEPFAR. President's Emergency Plan for AIDS Relief. PEPFAR Monitoring, Evaluation, and Reporting (MER 2.0) Indicator Reference Guide; 2017. Available from: https://www.pepfar.gov/ documents/organization/263233.pdf.

29. von Wichmann MÁ, Locutura J, Blanco JR, Riera M, Suárez-Lozano I, Saura RM, et al. GESIDA quality care indicators for the care of persons infected by HIV/AIDS. Enferm Infecc Microbiol Clin. 2010:28 Suppl 5:6-88

30. The Global Fund 35th Board Meeting. 2017-2022 Strategic Key Performance Indicator Framework GF/B35/07 A Revision 1 . Abidjan: board Decision; 2016.

31. Valdiserri RO, Forsyth AD, Yakovchenko V, Koh HK. Measuring what matters: development of standard HIV core indicators across the U.S. Department of health and human services. Public Health Rep. 2013;128:354-9.

32. Shekelle PG, MacLean CH, Morton SC, Wenger NS. Assessing care of vulnerable elders: methods for developing quality indicators. Ann Intern Med. 2001:135:647-52

33. McGlynn EA, Asch SM, Adams J, Keesey J, Hicks J, DeCristofaro A, et al. The quality of health care delivered to adults in the United States. N Engl J Med. 2003;348:2635-45.

34. Barros AJ, Hirakata VN. Alternatives for logistic regression in cross-sectional studies: an empirical comparison of models that directly estimate the prevalence ratio. BMC Med Res Methodol. 2003:3:21.

35. Passin WF, Kim AS, Hutchinson AB, Crepaz N, Herbst JH, Lyles $\mathrm{CM}$, et al. A systematic review of HIV partner counseling and referral services: client and provider attitudes, preferences, practices, and experiences. Sex Transm Dis. 2006;33:320-8.

36. Chesney MA. The elusive gold standard. Future perspectives for HIV adherence assessment and intervention. J Acquir Immune Defic Syndr. 2006:43 Suppl 1:S149-55

37. Harrigan PR, Hogg RS, Dong WW, Yip B, Wynhoven B, Woodward J, et al. Predictors of HIV drug-resistance mutations in a large antiretroviral-naive cohort initiating triple antiretroviral therapy. J Infect Dis. 2005;191:339-47

38. Bangsberg DR, Perry S, Charlebois ED, Clark RA, Roberston M, Zolopa AR, et al. Non-adherence to highly active antiretroviral therapy predicts progression to AIDS. AIDS. 2001;15:1181-3.

39. Mills EJ, Nachega JB, Buchan I, Orbinski J, Attaran A, Singh S, et al. Adherence to antiretroviral therapy in sub-saharan Africa and North America: a meta-analysis. JAMA. 2006:296:679-90.

40. Costa JM, Torres TS, Coelho LE, Luz PM. Adherence to antiretroviral therapy for HIV/AIDS in Latin America and the caribbean systematic review and meta-analysis. J Int AIDS Soc. 2018; 21:e25066

41. Duggal S, Chugh TD, Duggal AK. HIV and malnutrition: effects on immune system. Clin Dev Immunol. 2012;2012:784740.

42. Petersen M, Yiannoutsos CT, Justice A, Egger M. Observational research on NCDs in HIV-positive populations: conceptual and methodological considerations. J Acquir Immune Defic Syndr. 2014;67 Suppl 1:S8-16

43. Tang AM, Quick T, Chung M, Wanke CA. Nutrition assessment counseling, and support interventions to improve health-related outcomes in people living with HIV/AIDS: a systematic review of the literature. J Acquir Immune Defic Syndr. 2015;68 Suppl 3.5340-9.

44. Nakimuli-Mpungu E, Bass JK, Alexandre P, Mills EJ, Musisi S, Ram $\mathrm{M}$, et al. Depression, alcohol use and adherence to antiretroviral therapy in sub-saharan Africa: a systematic review. AIDS Behav. 2012;16:2101-18

45. Lu HF, Hsiao FH, Sheng WH, Liao SC, Wu PY, Yang YL, et al. Prevalence and predictors of depression among people living with HIV/AIDS: a National study. Nurs Res. 2018;67:379-86.

46. Wolff $L C$, Alvarado M R, Wolff RM. Depression in HIV infection: prevalence, risk factors and management. Rev Chilena Infectol. 2010;27:65-74.

47. Feuillet P, Lert F, Tron L, Aubriere C, Spire B, Dray-Spira R, et al. Prevalence of and factors associated with depression amons people living with HIV in France. HIV Med. 2017:18:383-94.

48. World Health Organization. Factsheet on HIV-Associated Tuberculosis. WHO; 2018. Available from: https://www.who.int/tb/ areas-of-work/tb-hiv/tbhiv factsheet.pdf?ua $=1$

49. Silow-Carroll S, Edwards JN, Rodin D. Using electronic health records to improve quality and efficiency: the experiences of leading hospitals. Issue Brief (Commonw Fund). 2012;17:1-40.

50. Pérez-Cuevas R, Doubova SV, Jasso-Gutiérrez L, Flores-Hernández S, Cuevas GO, Aranza-Doniz C, et al. Evaluation of the quality of care of neonates with necrotizing enterocolitis affiliated with seguro popular in Mexico. Bol Med Hosp Infant Mex. 2014:71:76-82. 